\title{
Nutritional causes of obesity among young women
}

\author{
Emanuela Dziony ${ }^{1}$, Elżbieta Poniewierka ${ }^{2}$ \\ ${ }^{1}$ Wroclaw Medical University, Poland \\ 2Division of Dietetics, Department of Gastroenterology and Hepatology, Wroclaw Medical University, Poland
}

\begin{abstract}
Introduction: Obesity is a consequence of abnormal lifestyle and poor nutrition. The aim of this paper was to show the relation between the way of nutrition and physical activity, and the increased body weight among young women.
\end{abstract}

Material and methods: The survey was conducted between June and October 2014 among 176 women from all parts of Poland, at the age between 16 and 25 years. The survey was conducted on the basis of a survey questionnaire consisting of questions that covered the dietary preferences, the frequency of eating particular dietary products, and physical activity. Women were divided into two age groups, and the results that were drawn from both groups were compared.

Results: Every third interviewee did not eat breakfast every day, every fifth ate her last meal too late. Women were characterised by low physical activity. The majority of them spent their free time passively, and only a small percentage of interviewees performed certain physical exercises. A large group of respondents ate highly calorific desserts. On the other hand, desserts based on fruit were eaten only by one third of the researched group. The scant amount of fruit and vegetables that should be eaten was also proven. Seventy percent of the interviewees did make certain ineffective dieting attempts.

Conclusions: In the interviewed group of young, obese women we noted a range of abnormalities connected with the way of nutrition and the quality of eating products. It was seen that physical activity reduced along with increasing age. Every second respondent, in spite of their young age, complained about chronic ailments that may appear as a result of obesity. That is why it was concluded that the cause of obesity was inappropriate diet and lifestyle.

Key words: obesity, nutrition, physical activity.

\section{Introduction}

Obesity is an illness that causes accumulation of body fat in the organism, which leads to the impairment of its regular functioning [1]. The body fat content in the organism should be maintained at a level of $20-25 \%$ [2]. When the content increases the norm, we face obesity. When the excess abdominal fat accumulates around thighs, hips, and buttocks is it called gynoid obesity, usually affecting women, whereas android obesity, mostly affecting men, is the case where the excess abdominal fat accumulates around stomach, nape, shoulders and around internal organs [3].

To define obesity the amount of fat and its distribution in the body must be evaluated. Most frequently, this is done using anthropometric methods (BMI, WHR), which shows not only the obesity rate, but also its type [1].

The proportion of obese people in particular countries differs. The main cause of high body mass index is inappropriate lifestyle - too much consumption of highly calorific food and too low physical activity $[1,4]$. According to studies from 2009, the majority of obese, adult women live in the United States of America (36.5\%), Mexico (34.5\%), and Chili (30.7\%). The smallest proportion of obese women live in India (2.8\%), China (3.4\%), and Japan (3.5\%). In Poland this proportion is about $12 \%$. The epidemiological data is alarming and it indicates that the proportion of obese people is still increasing and will continue to increase in the future [5]. 
The overdevelopment of body mass is influenced by a range of factors, such as environment, physiology, genetics, psychology, and pharmacology $[1,6,7,8]$.

Obesity was qualified by the World Health Organisation (WHO) as a chronic, non-infectious illness. Being overweight usually leads to being more vulnerable to illnesses, fatality, and worsening of quality of life. According to epidemiological research, the risk of death increases with the increase of body mass index (BMI). Illnesses of the circulatory system, usually connected with obesity, for instance heart ischaemia, hypertension, and myocardium insufficiency, are the most common illnesses that lead to premature death. Type II diabetes is seen in $90 \%$ of obese people. Obesity is also claimed to be an indirect cause of many types of cancer. The connection between obesity and cancers is still not clear enough, although many types of research on a large scale are currently being conducted. One theory says about secretion of tumour necrosis factor, TNFa, from fat cells. Greater quantities of cytokine are secreted by cells from overweight people and those with insulin resistance, which increases the risk of atherosclerotic lesions, but also has a carcinogenic influence $[1,4,9]$.

The basic method of treating obesity is cutting down the body mass. Even $10 \%$ less weight has a very good impact on the organism. It is very important to bear in mind that losing weight should be a slow, continuing process and, what is also crucial, should not exceed 0.5-1 kilo per week. A change of lifestyle and foregoing eating habits is necessary. Diet, which plays a key role, should be energy balanced and should provide all necessary nutritional elements, vitamins, and mineral elements in appropriate quantities. An inherent element of the dietary therapy is increased physical activity. In treating obesity, one can also apply certain pharmacological therapy, but it should be considered only when new diet and increased physical activity do not meet expectations [2,6,10-12].

\section{Material and methods}

The research involved women from all over Poland, in the age range 16-25 years. Those people who took part in this survey answered all questions via the internet. The survey questionnaire was correctly completed by 176 overweight or obese women. The questionnaire consisted of 39 questions. In three of the questions, there was a possibility of a multiple choices, and for the rest of the questions there could be only one option chosen.

The women who participated in the survey were divided into two age groups: a group of younger women: age between 16 and 20 years (63 respondents) and older women: age between 21 and 25 years (113 women).

The answers for all the questions were added by Microsoft Office Excel program. Later on, the answers from both groups were analysed statistically. For the analysis the independence test $\chi^{2}$ (squared chi) was used. The difference at the materiality level was considered as very important for statistical issues. The results are presented in Tables 1 and 2.

Every third woman did not eat breakfast every day. Twenty-two percent of women from both groups had their last meal too late before going to sleep. Only $8 \%$ of respondents from the younger and $2 \%$ respondents from the older group evaluated their physical activity as high. Half of the respondents from both groups admitted spending their free time passively - watching TV or reading (48\% and 56\%). A significant majority of the women conceded that they snacked between meals, always or at least from time to time. Five percent of the younger and $7 \%$ of the older respondents avoided desserts and sweets. Respectively, $6 \%$ and $5 \%$ of them ate a dessert or some sweets a few times a day. Most frequently they consumed chocolate bars (57\%), sweets (43\%), and least frequently they ate desserts containing fruit (29\% respondents from both groups). Every fifth interviewee, in both groups, did not eat wholemeal baked goods or coarse-grained grits, and only $19 \%$ of the younger and $16 \%$ of the older women ate those products every day. Most of the women preferred poultry (88\% and $85 \%$ ), although the most frequently chosen method of cooking was frying. $37 \%$ of women from the first and $47 \%$ of women from the second group did not add any vegetables to their meals. Respectively, $48 \%$ and $67 \%$ had only one portion of fruit during the day, and $2-3$ portions were eaten by $46 \%$ of the younger and $29 \%$ of the older women. Beverages are not sweetened by about $50 \%$ of the respondents, but $26 \%$ respondents from the first and $22 \%$ respondents from the second group sweetened coffee or tea by adding at least two spoons of sugar. $70 \%$ of the younger and $79 \%$ of the older interviewees drank alcohol. Most frequently they chose beer (45\% and 49\%). Slimming trials with the help of 'popular diets' (like Dukan's or Cabbage) were essayed by a large number of women, in the first one by $70 \%$ and in the second by $65 \%$ of interviewees. Desirable effects were achieved by only $3 \%$ of the younger and $7 \%$ of the older obese women. A significant proportion of young women, despite their age, had a range of chronic afflictions, which might have resulted from obesity ( $48 \%$ and $55 \%)$.

\section{Discussion}

The correct nutrition model should consist of 4-5 meals a day. The proper quantity of meals was followed by only $60 \%$ of the interviewees. A dozen or so per cent of women had more than five meals a day. In research made by Stefańska et al. it was pointed out that five meals a day were eaten by only $22 \%$ of women with increased Body Mass Index [13]. In research of Szczepańska and 
Table 1. Rating of nutritional factors that can affect excessive body weight in young women

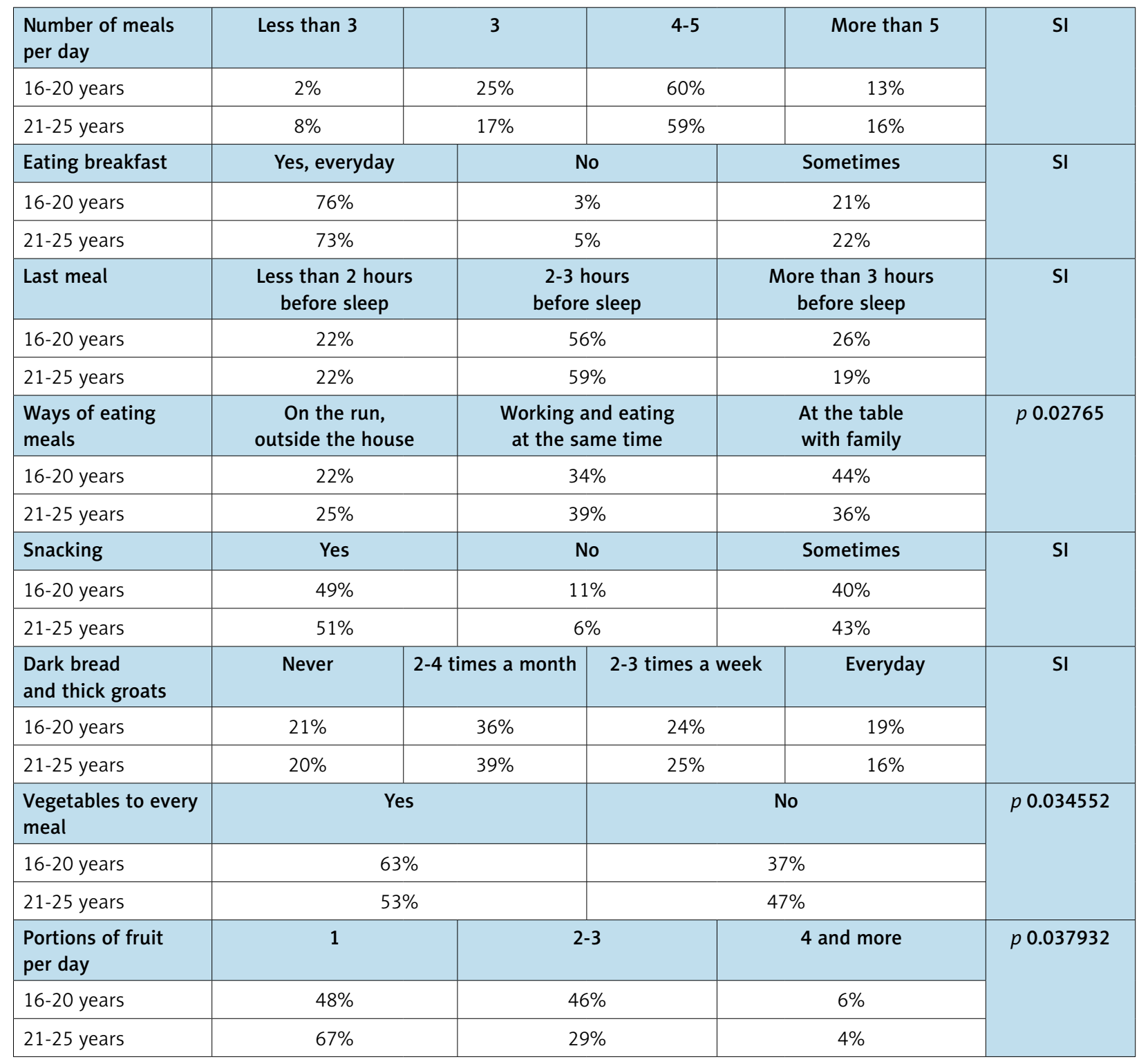

Table 2. Rating of physical activity of young women

\begin{tabular}{|c|c|c|c|c|c|}
\hline $\begin{array}{l}\text { Rating of physical } \\
\text { activity }\end{array}$ & I'm not very active & \multicolumn{2}{|c|}{ I'm averagely active } & I'm very active & \multirow[t]{3}{*}{ SI } \\
\hline $16-20$ years & $44 \%$ & \multicolumn{2}{|c|}{$48 \%$} & $8 \%$ & \\
\hline $21-25$ years & $49 \%$ & \multicolumn{2}{|c|}{$49 \%$} & $2 \%$ & \\
\hline Doing sport & I do not do sports & 2-4 times a month & 2-3 times a week & Everyday & \multirow[t]{3}{*}{$p 0.043972$} \\
\hline $16-20$ years & $19 \%$ & $38 \%$ & $27 \%$ & $16 \%$ & \\
\hline $21-25$ years & $27 \%$ & $35 \%$ & $34 \%$ & $4 \%$ & \\
\hline $\begin{array}{l}\text { Ways of spending } \\
\text { free time }\end{array}$ & $\begin{array}{l}\text { Watching TV, } \\
\text { reading }\end{array}$ & Sport & Social gatherings & Resting & \multirow[t]{3}{*}{ SI } \\
\hline $16-20$ years & $48 \%$ & $8 \%$ & $20 \%$ & $24 \%$ & \\
\hline $21-25$ years & $56 \%$ & $3 \%$ & $20 \%$ & $21 \%$ & \\
\hline
\end{tabular}


Brończyk-Puzoń, the correct eating habit model was executed by only $36 \%$ of women [14]. On the other hand, Ostrowska et al. showed that the proper number of meals were eaten by $62 \%$ of women from the survey, and Mędrala-Kuder showed that more than three meals a day were eaten by $61 \%$ of women $[15,16]$.

More than $70 \%$ of the interviewees, regardless of their age, had breakfast every day, and a little more than $20 \%$ of them had breakfast only sometimes. Comparing the results from the survey with the ones from other authors, we can cite from the research conducted by Lange et al. that having breakfast every day was followed by $67 \%$ of women, similarly as in our case [17]. In research done by Wyka and Żechałko-Czajkowska $45 \%$ interviewees did not have breakfast at all [18].

The time between having the last meal and going to sleep is also crucial. More than $20 \%$ of women had that last meal too late, but also there was a significant proportion of women who had it too early. The right habit of having the last meal 2-3 hours before going to bed was suitable for about half of the interviewees in both age groups.

Physical activity is a favourable element of a healthy lifestyle and has an impact on enhancing one's health as well as increasing energy expenditure, which helps to maintain correct body weight. Obese women who took part in the survey evaluated their physical activity, and the results were adverse. Only $8 \%$ of younger women and $2 \%$ of older women committed to exercise regularly, and almost half of all the women, regardless of their age, committed to low physical activity. Cymerys and Olek proved that average physical activity is fulfilled by $44 \%$ of interviewees and high physical activity by $4.2 \%$ [19]. Nevertheless, the results from Bronkowska et al. present differently: $4.8 \%$ women certified low physical activity, $33.3 \%$ moderate, and $47.6 \%$ high activity [20]. Those women who declared high physical activity, in both age groups, did sport every day. In this survey, it was shown that $19 \%$ of the younger women did not do any sport at all, and $16 \%$ of them did it every day. In the group of older women $27 \%$ of them did not do any physical activities, and only $4 \%$ of them did some sport every day. In research done by Bronkowska et al. 14\% of the women did not do any physical activity at all [20]. About 23\% of the women who took part in the WOBASZ survey admitted doing exercises every day [21]. It is advised for overweight people to do at least the average number of activities a few times a week. The majority of interviewed women marked low physical activity or admitted to being averagely active, which contributes to being physically active only 2-4 times a month.

A significant proportion of the interviewed women had a bad habit of eating meals in a hurry or while working. This habit aids obesity. Only $57 \%$ of the women from the younger group and $36 \%$ of the women from the older group ate meals while not being in a hurry. Another bad and very common habit is snacking between meals. A big proportion of women in all age groups stated that they snack, and usually they preferred having high-calorie or salty snacks. According to Centrum Badania Opinii Społecznej (CBOS) from September 2014, 72\% of Polish people snack between meals every day or at least sometimes [22]. In the survey conducted by Cymerys and Olek it was shown that $48 \%$ of people snack every day, and $29 \%$ snack often but not every day [19]. Lange et al. proved that everyday snacking was characterised by $25 \%$ of interviewees, but on the other hand, Wyka and ŻechałkoCzajkowska confirmed that even $78 \%$ of obese women from Wrocław snacked at least sometimes $[17,18]$. In our survey both groups of women, when snacking, usually chose sweets: $42 \%$ and $46 \%$, respectively. Salty snacks were chosen more often by older women $-23 \%$; on the other hand, younger women chose fruit. Also, Cymerys and Olek found that most frequently women chose sweets (54\%) and fruit [19].

The vast majority of people spend their free time passively; only $8 \%$ women from the first group and $3 \%$ from the second group spend their free time participating in sports. It is the following evidence that women from this research have low physical activity, and the vast majority - $48 \%$ and $56 \%$, respectively - spend their free time passively, sitting or lying.

Consuming products that have a low glycaemic index has a favourable impact on metabolic processes of the organism, which is why wholemeal baked goods, pasta, and coarse-grained grits should be present in our everyday diet. In the conducted survey, it was proven that in the younger group $27 \%$ of women had normal baked goods, every third had wholemeal goods, and $30 \%$ of interviewees had mixed goods. The incidence of consuming wholemeal baked goods and coarse-grained grits is unsatisfactory. Those products are eaten every day by $19 \%$ of younger and $16 \%$ of older women. Two or three times a week wholemeal baked goods and coarse-grained grits were eaten by, respectively, $24 \%$ and $25 \%$ of respondents. A similar proportion of women did not eat those products at all. Szczepańska and Brończyk-Puzoń proved that wholemeal bake goods and coarse-grained grits were consumed by $42 \%$ of women who took part in their research, which is two times higher than the women from our research [14]. In research by Lange et al., one third of the respondents admitted to eating wholemeal baked goods every day [17]. Cymerys and Olek showed that grits or rice were consumed rarely than once a week or sometimes they were not consumed at all [19]. Stefańska et al. gained a similar result to ours, stating that $33 \%$ of women ate wholemeal products every day [23].

A very common appearance in the researched group is the consumption of desserts. Most frequently, women 
reach for cakes, cookies, and buns, more than half of the respondents (57\%) ate chocolate products, and every second ate ice-cream. Only $27 \%$ of women from the younger group ate desserts made of fruit. With equal frequency, women from the older group ate traditional desserts. In research conducted by Stefańska and Brończyk-Puzoń $11 \%$ of respondents did not eat any sweets at all, and $37 \%$ of respondents ate them from time to time. On the other hand, Lange et al. showed that more than $50 \%$ of women had sweets 2-3 times a week [14,17].

In our survey, the most frequently chosen meat was poultry, which was eaten by, respectively, $89 \%$ and $85 \%$ of respondents. A similar result was gained by Szczepańska and Brończyk-Puzoń - 90\% of women most frequently chose poultry [14]. From our research it was concluded that $50 \%$ of women use frying as the most popular method of preparing meat. In research by Kardjalik et al. almost half of the interviewees chose frying for preparing meat, and in Cymerys and Olek's research the result was $60.5 \%$ [19]. As can be concluded from those analyses, the most preferable and commonly used method of preparing meat was frying, which is the least favourable and healthy choice for overweight people, since frying makes meals more calorific.

Fat in the diet should be controlled as far as both quality and quantity are concerned. In our research, we established that a critical proportion of women used butter for spreading bake goods in both groups (30\% and 43\%). Szczepańska and Brończyk-Puzoń observed that $46 \%$ of respondents used soft margarine, and $21 \%$ women did not spread anything on baked goods [14]. Bronkowska et al. gained different results. In their research $19 \%$ of women used soft margarine and $48 \%$ used butter [20]. Stefańska et al. concluded from their survey that butter is used by more than a half of respondents (55\%) and margarine by $27 \%$ of them [23].

Fruit in a quantity of one portion per day was consumed by $48 \%$ of women from the first, and $67 \%$ of women from the second group. Two or three portions a day were eaten by $46 \%$ and $29 \%$ of younger and older women, respectively, and four or more portions by $6 \%$ of younger and $4 \%$ of older women. On the other hand, vegetables were an addition to each of the main meals for $63 \%$ and $53 \%$ of respondents from both groups, respectively.

Simple sugars are also provided with sweetened beverages. It was established from the research that one quarter of the respondents in both age groups added a lot of sugar to their drinks. In Cymerys and Olek's research it was established that more than $36 \%$ of the women drank tea or coffee that was sweetened with at least two spoons of sugar [19]. On the other hand, Gawęcki et al. observed that 70\% of respondents drank tea or coffee without any sugar [25].

One gram of pure alcohol provides $7 \mathrm{kcal}$. The majority of interviewed women drank mostly beer, and it is done much more often by older women. Our results can be compared with the research by Szczepańska and Brończyk-Puzoń, in which $37 \%$ of women did not drink alcohol at all [14]. According to the report conducted by TNS Poland in 2012, among people over 18 years old, only every fifth woman admitted to sobriety [26].

About $70 \%$ of respondents, regardless of age, used to diet. In most cases, women did not ask for the advice of any dietitians, which led to ineffective dieting. A minor proportion of women were able to maintain the weight achieved by cutting down on some products. In Lange et al.'s research 9 out of 10 interviewed women used to try to lose some extra weight [17]. In Sadowska and Szuber's research this proportion was slightly smaller [27]. In our research about $80 \%$ of women, in both age groups, indicated having overweight members in their families. In Lange et al.'s research more than half of the respondents admitted having at least one overweight parent [17].

Obesity is an illness that is related to a range of serious afflictions, for instance hypertension and type II diabetes as well as disorders of osteoarticular system functioning. Despite their very young age, every second respondent complained about certain afflictions (48\% and 55\%). In the younger group, every fifth (21\%) woman complained about joint aches or pain in the spine, and one 1 in 10 had hypertension. In the older group $29 \%$ of respondents complained about osteoarticular system afflictions, and $9 \%$ of them had hypertension. After a detailed analysis of this problem, it was concluded that the more active a person is, the less frequently the person complains about his or her health.

In this simple survey, it was proven that in most cases the causes of being overweight or obese are the results of abnormal nutrition and lack of physical activity.

\section{Disclosure}

Authors report no conflict of interest.

\section{References}

1. Jarosz M, Dzieniszewski J. Otyłość. Zapobieganie i leczenie. Wydawnictwo Lekarskie PZWL. Warszawa 2006.

2. Ciborowska H, Rudnicka A. Dietetyka. Żywienie zdrowego i chorego człowieka. Wydawnictwo Lekarskie PZWL. Warszawa 2012.

3. www.izz.waw.pl/.

4. Kłosiewicz-Latoszek L. Otyłość jako problem społeczny, zdrowotny i leczniczy. Problemy Higieny i Epidemiologii 2010; 91: 339-343.

5. www.czytelniamedyczna.pl/.

6. http://www.farm.amwaw.edu.pl/ axzimni/biuletyn/.

7. http://www.dietetycyonline.pl.

8. Pilska M, Jeżewska-Zychowicz M. Psychologia żywienia. Wybrane zagadnienia. Wydawnictwo SGGW, Warszawa 2008.

9. Malinowski M, Deja MA, Gołba KS, et al. Wpływ okołonaczyniowej tkanki tłuszczowej na funkcję naczyń. Kardiol Pol 2008; 66 (supl. 3): 317-325.

10. Tatoń J, Czech A, Bernas M. Otyłość. Zespół metaboliczny. Wydawnictwo Lekarskie PZWL, Warszawa 2007. 
11. Białkowska M. Etiopatogeneza otyłości. Postępy Nauk Medycznych 2011; 9: 765-769.

12. Smołka K. Dietetyczne i farmakologiczne leczenie nadwagi i otyłości. Journal of NutriLife 2012, 12; http://www.Nutrilife.pl/ index.php?art=63 [dostęp: 2017.08.28].

13. Stefańska E, Ostrowska L, Czapska D, Karczewski J. Wartość odżywcza positków w dietach kobiet o prawidłowej i nadmiernej masie ciała. Rocz Panstw Zakl Hig 2010; 61: 201-205.

14. Szczepańska E, Brończyk-Puzoń A. Ocena nawyków żywieniowych pacjentów z otyłością, zakwalifikowanych do zabiegu bariatrycznego. Medycyna Ogólna i Nauki o Zdrowiu 2014; 20: 330-334.

15. Ostrowska L, Czapska D, Karczewski J, Krzemińska A. Zachowania żywieniowe osób z nadwagą i otyłością. Bromat Chem Toksykol 2002; 35: 139-146.

16. Mędrala-Kuder E. Wybrane zwyczaje żywieniowe w grupie kobiet z nadwagą lub otyłością. Rocz Panstw Zakl Hig 2005; 56: 371-377.

17. Lange E, Krusiec J, Kulik A. Wybrane zachowania żywieniowe kobiet i mężczyzn z nadmierną masą ciała. Probl Hig Epidemiol 2011; 92: 580-582.

18. Wyka J, Żechałko-Czajkowska A. Spożycie grup produktów wśród otyłych mieszkańców Wrocławia. Rocz Panstw Zakl Hig 2008; 59: 231-236.

19. Cymerys M, Olek E. Ocena nawyków żywieniowych i stylu życia wśród chorych z otyłością brzuszną. Prz Kardiol 2011; 6: 287-293.

20. Bronkowska M, Martynowicz H, Żmich K, et al. Wybrane elementy stylu życia oraz wiedza żywieniowa otyłych osób z rozpoznanym nadciśnieniem tętniczym. Nadciśn Tętn 2009; 13: 266-274.

21. Główny Urząd Statystyczny: Stan zdrowia ludzkości Polski w 2009 r. Warszawa 2011 (www.stat.gov.pl).

22. Centrum Badania Opinii Społecznej: Zachowania żywieniowe Polaków. Warszawa 2014; 115.

23. Stefańska E, Ostrowska L, Czapska D, Karczewski J. Częstotliwość spożycia wybranych produktów przez osoby otyłe. Bromat Chem Toksykol 2008; 51: 716-719.

24. Kardjalik K, Bryła M, Maniecka-Bryła I. Zachowania zdrowotne związane z odżywianiem oraz występowanie nadwagi i otyłości w grupie studentów. Probl Hig Epidemiol 2012; 93: 71-79.

25. Gawęcki J, Twardowska M, Łoboda D. Zwyczaje młodzieży akademickiej dotyczące spożywania napojów - badania wstępne. Żywn Nauka Technol Jakość 2009; 4: 204-210.

26. TNS: Spożycie alkoholu w Polsce w 2012 r. Raport z badań. Październik 2013.

27. Sadowska J, Szuber M. Ocena stosowanych metod odchudzających oraz używania preparatów wspomagających odchudzanie przez młode kobiety. Rocz Panstw Zakl Hig 2011; 62: 343-350. 